\title{
1 Infertility and the Purposes of Marriage in Legal Theory
}

\section{The childless marriages of the Prophet Muhammad and the depiction of infertile spouses in the hadith: two conflicting views}

Some Islamic laws concerning women are traditionally considered to have been derived from the Prophet Muhammad's family life. These include laws pertaining to seclusion and veiling, adoption and kinship, sexual etiquette and negotiation within polygamous marriages, the procedure for dealing with accusations of marital infidelity, and others. Women's forms of purification from menses in preparation for prayer are also traced back to the practices of the Prophet's own family. ${ }^{42}$ The tradition of permitting young girls to play with dolls is based on 'A' 'isha's (d. 58/678 ${ }^{43}$ ) childhood in the Prophet's home. ${ }^{44}$ Some have attributed the willingness to allow Muslim women to participate in the transmission of hadith to the precedent of the Prophet's wives and daughters transmitting them. ${ }^{45}$ However, not all aspects of the Prophet's household became precedents for deriving Islamic law. For example, the number of the Prophet's simultaneous marriages is held to be exceptional rather than paradigmatic for the Islamic laws of marriage.$^{46}$ With this in mind, the question arises as to whether Islamic legal attitudes toward infertility have any relation to the Prophet Muhammad's personal example.

\section{Mothers of the believers}

Most of the Prophet Muhammad's marriages were childless but there is a remarkably scant record of people commenting on that fact. Only two of Muhammad's

42 M. H. Katz, Body of the Text (Albany: SUNY Press, 2002), 85, 97. A. Sayeed, Women and the Transmission of Religious Knowledge in Islam (Cambridge: Cambridge University Press, 2013), 30. 43 Here as elsewhere, Islamic calendar dates (A.H.) are followed by Christian ones (A.D.).

44 Al-Bukhārī (d. 256/870), Șaḥị al-Bukhārī (Vaduz, Liechtenstein: Thesaurus Islamicus Foundation, 2000), 78 (adab):81 = no. 6130 .

45 This too had its limits, as there were those who believed that the Prophet's wives represented the exception rather than the rule. Sayeed, Women and the Transmission of Religious Knowledge in Islam, $63 \mathrm{ff}$.

46 Katz, Body of the Text, 73.

Ә OpenAccess. (C) 2020 Sara Verskin, published by De Gruyter. (cc) BY-NC-ND This work is licensed under the Creative Commons Attribution-NonCommercial-NoDerivatives 4.0 License.

https://doi.org/10.1515/9783110596588-004 
many marriages and liaisons resulted in children and, of the children he did produce, no son survived childhood and only one daughter, Fāțima (d. 11/633), survived her father. ${ }^{47}$ Muhammad is reported to have impregnated two women, his first wife Khadīja (d. 619) and Māriyya the Copt (d. 16/637). ${ }^{48}$ Some of the other women with whom he had sexual relations did have children from previous husbands, but not from him. With the exception of 'A' 'isha, all of his wives had been previously married, although some of those marriages were of short duration and during times of war. In total, approximately half of the wives and concubines associated with Muhammad had no children at all, or there are conflicting reports about them. ${ }^{49}$ In part, this can be attributed to the unusual patterns of fertility that occur in a society with high rates of divorce, premature death, and warfare. ${ }^{50}$ For all of these reasons, it is difficult to determine the exact reason for the high number of childless unions in Muhammad's family.

The Prophet Muhammad does not appear to have devalued his childless marriages, quite the contrary. With some exceptions, his wives were held in high esteem in their own lifetimes and in the subsequent generations. Although a well-known hadith has the Prophet praising his late wife Khadija to his beloved but jealous wife ' $\bar{A}$ 'isha on the grounds that Khadija gave him children, there is otherwise but little mention of childlessness as a source of strain in his mar-

47 In addition to his descendants through Fāṭima, Muhammad also had two grandchildren from his daughter Zaynab and one from his daughter Ruqayya. The marriage between the Prophet's daughter Umm Kulthūm and 'Uthmān was childless. Zaynab's son 'Alī died young while her daughter Umāma survived into adulthood and married 'Alī ibn Abī Țālib, after the death of her aunt Fāṭima. She bore him a son, Hilāl. Muhammad's grandson, from the union between his daughter Ruqayya and 'Uthmān, died in childhood. The household thus remained small. Ibn Sa‘d (d. 230/845), al-Ṭabaqāt al-kubrā (Beirut: Dār Iḥya’ al-Turāth al-'Arabī, 1996) 8:252-262. On Muhammad's children, see Ibn Qayyim al-Jawziyya (d. 751/1350), Zād al-ma‘ād fī hady khayr al-'ibād (Beirut: Mu’assasat al-Risāla, 1998), 1:101.

48 There are some traditions in which 'A' 'isha is said to have told Muhammad that Māriya's son Ibrāhīm was not his. Some Shī'ī commentaries on Q. 24:11, e.g. Tafsìr al-Qummī say that the verse refers to this incident. Al-Qummī, Tafsìr al-Qummī (Qum: Mu'assasat al-Imām al-Mahdī, 2014) 2:702.

49 These are 'Ā’isha, Ḥafșa, Zaynab bt. Khazayma, Zaynab bt. Jaḥsh, Juwayriyya, Șafiyya, Maymūna, and Rayhāna.

50 There is a large body of scholarly literature about the extent to which polygyny, as it is practiced in the twentieth century, itself reduces the fertility of women in such marriages in comparison to women in monogamous marriages. The correlation between depressed fertility in polygynous families is sometimes attributed to chemical-biological factors and sometimes to socioeconomic factors, while other scholars deny that there is a significant correlation at all. See K. Effah, "A Reformulation of the Polygyny-Fertility Hypothesis," Journal of Comparative Family Studies 30 (1999), 381-408. 
riages. ${ }^{51}$ While there are many traditions which report discussions between $\mathrm{Abu}$ Bakr and his daughter 'Ā'isha, and 'Umar and his daughter Hafșa (d. 45/665), regarding their relationships with Muhammad, I have not found one that addresses their childlessness. ${ }^{52}$ Similarly, there is no record of Muhammad's wives or enemies overtly accusing the Prophet himself of diminished fertility. ${ }^{53}$ Some modern feminist Muslims have pointed to the example of Muhammad's wives, revered in the Islamic tradition as the "mothers of the believers," as icons demonstrating the value of childless women ${ }^{54}$ although, to my knowledge, no medieval source makes this positive connection. ${ }^{55}$

\section{Infertility in the hadīth}

In spite of the Prophet's personal example, many hadiths associated with Muhammad and 'Umar (d. 23/644), father of Muhammad's childless wife Hafșa, reference fertility as an essential trait to seek out in a spouse. Fertility is correlated with several other desirable traits, including virginity and amiability. Other hadiths suggest that even when an infertile woman is otherwise desirable, her inability to conceive disqualifies her as a prospective spouse.

The following are some of Muhammad and 'Umar's statements about infertile women.

51 E.g. Al-Bukhārī, Șaḥịh al-Bukhārī, 63 (manākib al-ansār):20 = no. 3818. Another exception occurs in a tradition where 'Â'isha says of Māriya Umm Ibrāhīm: "Then God granted him a child through her and kept us from having one.” Ibn Sa‘d, Țabaqāt, 8:213. One could also perhaps interpret the following passage from Ibn Sa'd's biography of 'A''isha, a passage which is immediately preceded by discussions of the consummation of her marriage, as a request for a child: "I said to him, 'O Messenger of God, women are supposed have a kunya, so give me a kunya.' He said, 'Take on as your kunya your son 'Abdallāh,'” i.e. her nephew's name. Ibn Sa'd, Țabaqāt, 8:274, 275. See D. Spellberg, Politics, Gender and the Islamic Past (New York: Columbia University Press, 1994), 41.

52 E.g. al-Bukhārī (d. 256/870), Șaḥịh al-Bukhārī, 46 (bab al-mazālim):25 = no. 2468.

53 The one time Muhammad's fertility is addressed is in a hadith in which he argues that he has proof that he is not the anti-Christ (dajjāl). Muhammad says that whereas the anti-Christ is infertile and cannot sire children, he (Muhammad) has sired children. Muslim ibn al-Ḥajjāj (d. 261/ 875), Șahịh Muslim (Beirut: Dār Ihyyā’ al-Turāth al-'Arabī), 4:1783 = no. 2927.

54 See, for example, A. Chaudhry, "Unlikely Motherhood in the Qur'ān: Oncofertility as Devotion" in Oncofertility: Reflections from the Humanities and Social Sciences, ed. T. K. Woodruff et al. (New York: Springer, 2010), 287-94.

55 See Kueny, Conceiving Identities: Maternity in Medieval Discourse and Practice, 110-14. Kueny shows that even those medieval commentators who had positive attitudes toward 'A' 'isha still noted her infertility as an imperfection. 
Ma'qil b. Yasār (d. 59/679 in Bașra) said: A man came to the Prophet and said "I have found a noble and beautiful woman, but she is infertile. Should I marry her?” He said: "No.” Then he came to him a second time and he [again] forbade him. Then he came to him a third time and [the Prophet] said: "Marry amiable, fertile women so that I [God] may make you abundant among the nations." ${ }^{56}$

From Ibn Jurayj (d. 150/767 in Mecca): A man came to the Prophet and said: “O Messenger of God, I have a cousin who is the most noble-minded of women but she is barren.” The Messenger of God said: "Do not marry her." Then he said. "Marrying a fertile black woman is better than marrying a fair woman who is infertile. I taught you that a miscarried fetus who is the offspring of Muslims is told: 'Enter Paradise!' He remains, full of indignation, at the gate of Paradise and says: 'I will not enter paradise until my parents do.' So he is told: 'Then enter Paradise, by the grace of the mercy of God."

From Anas b. Malik (d. 91/709 in Bașra): [The Prophet] said, "Marry amiable, fertile women and multiply, for I will make great the number of prophets among you on the Day of Resurrection. Beware of the barren woman, for [one married to] her is like a man ensconced at the top of a well, who waters his land daily, but whose land does not bloom, the stream [of water] is not absorbed. ${ }^{58}$

Abū Dāwūd said: 'Umar said: "A mat in the house is better than a woman who does not produce children." 59

The attitude manifested in these statements is summarized in Abū Ḥāmid alGhazālī’s (d. 505/1111) Ihyā 'ulūm al-dīn.

56 Abū Dāwūd (d.275/889), Sunan (Riyadh: Maktab al-Ma'ārif lil-Nashr, 1996), 311-12 = no. 2050, al-Nasā’ì (d. 303/915), Sunan (Riyadh : Maktab al-Ma‘āif lil-Nashr, 1996), 499 = no. 3227.

57 'Abd al-Mālik ibn Ḥabīb (d. 238/852), Kitāb adab al-nisā' al-mawsūm bi-kitāb al-ghāya wa'lnihāya (Paris: Dār al-Gharb al-Islāmī, 1992), 152. This statement indicates that the cousin in question is unable to conceive and the Prophet responds that she is useless, even in comparison to a lowly wife. He says that conception is itself useful even if no live baby results, since the fetus can compel God to allow his parents into heaven. In so doing, the Prophet differentiates between a woman who is unable to conceive and a woman who is unable to carry a fetus to term, even though in almost all other places in Arabic and Islamic literature, the diagnosis of infertility encompasses both conditions. See, for example, al-Shaybānī’s (d. 189/804) commentary on Q. 19:5 in which he glosses the word "barren woman" ('äqir) saying, "she does not menstruate, does not get pregnant, and does not give birth.” Muhammad ibn al-Ḥasan al-Shaybānī, Nahj al-bayān 'an kashf ma'ānī al-Qur'ān (Tehran: Nashr al-Hādī, 1998) 3:303.

58 Ibn Ḥabīb, Kitāb adab al-nisā' al-mawsūm bi-kitāb al-ghāya wa'l-nihāya, 152-3. There are many versions of this hadith which do not include the final sentence or which have a different conclusion, see al-Bayhaqī (d. 458/1066), al-Sunan al-kubrā (Beirut: Dār al-Kutub al-'Ilmiyya, 2003), 7:131.

59 Abū Dāwūd, Sunan, 589 = no. 3922. 
The second purpose [of having children] is endearing oneself to the Messenger of God and pleasing him by increasing that which he takes pride in. For the Messenger of God stated this explicitly, and everything which is said of "Umar clearly indicates an emphasis on the obligation of procreation. For he married a lot and said, "I marry for procreation." In the $a k h b \bar{r} r$ regarding the disparagement of the barren woman (madhammat al-mar'a al'aqim) it is reported that he, peace be upon him, ${ }^{60}$ said "A mat in the corner of the house is better than a woman who is infertile." He also said, "The best of your women are those who are fertile and amiable (al-wulūd al-wudūd). He also said, "A fertile black woman is better than a fair woman who does not produce children." ${ }^{61}$ This indicates that procreation is a superior virtue of marriage [in comparison to the virtue of] taming sexual excess, since fair women are more suitable for securing chastity, lowering one's gaze, and curbing desire. ${ }^{62}$

All of the above hadiths point to a tradition of forbidding, discouraging, and disdaining marriage to infertile women. It should be noted, however, that fertility is certainly not the only, or even the most common, virtue attributed to a good prospective wife. Other hadiths instruct men to seek out wives who are, among other things, believers, modest, beautiful, well-born, thrifty, wealthy, appreciative, and soft spoken. ${ }^{63}$ Among the most commonly mentioned, highly-prized attribute is that of virginity, which will be discussed below.

We thus have Muhammad's personal legacy of contracting and remaining in non-procreative marriages standing in contrast to the statements attributed to him and to 'Umar, father of the celebrated but childless Hafșa, that disparage and forbid such marriages. These negative statements are frequently found in $a d a b$ al-nis $\bar{a}$ ' (etiquette or religious guidance pertaining to women) literature, but their legal potential never seems to have been exploited in the formulation of Sunnī family law. Instead, the hadith most often cited in legal literature concerning infertility pertains to a sterile man:

[Reported from] Ibn Sīrīn: 'Umar b. al-Khațțāb sent a man on a tax collecting mission, and he married a woman. But he was infertile ('aqìm), and when he was brought before 'Umar

60 I have included the benediction here as there is some disagreement as to whether al-Ghazāli attributes this statement to 'Umar or to Muhammad himself. This formulation would indicate that the Prophet himself is meant, however the statement is elsewhere attributed to 'Umar. It is possible that the benediction was inserted by a later copyist, rather than by al-Ghazāli himself.

61 See al-Ṭabarānī (d. 360/971), al-Mu'jam al-kabīr (Cairo: Maktabat Ibn Taymiyya, 1983), 19:416 and Ibn Ḥibbān (d. 354/965), al-Majrūḥin min al-muḥaddithīn (Aleppo: Dār al-Wa‘y, 1975), 2:111. 62 Al-Ghazālī, Ihyā 'ulūm al-dīn (Cairo: Mu'assasat al-Ḥalabī, 1967), 2:26.

63 See Amāl Qarāmī, al-Ikhtilāf fì al-thaqāfa al-'arabìya al-islāmīya (Beirut: Dār al-Madār al-Islāmī, 2007), 37. 
this was mentioned to him and he said. "Did you inform her that you are infertile?" He said, "No." ['Umar] said, "Then divorce her and inform her, then give her the choice." ${ }^{64}$

Although this hadith is often cited in legal manuals, in discussions of laws pertaining to marital defects, it is usually immediately circumscribed or circumvented so as to limit or negate its impact, as will be explained later in this chapter.

In order to appreciate the significance of the radical divergence between Islamic law on the one hand, and the $a d a b$ al-nisä' literature culled from these $h a-$ diths on the other hand, it is worth examining the consequences of infertility in other religions.

\section{Infertility in the Islamic legal framework of sex and marriage, with comparisons to Christianity}

In Sex and Society in Islam: Birth Control Before the Nineteenth Century, Basim Musallam began his study of Islamic attitudes toward contraception by highlighting the contrasts between Christian and Islamic premises regarding sexuality and its role in marriage. It would serve us well to reiterate these contrasts when considering attitudes toward infertility. Musallam noted the following elements of Islamic sexual morality: marriage could be polygynous, and legitimate sexual intercourse could be had not only with wives, but also with concubines. Marriage was not viewed as a necessarily permanent relationship because divorce was easy to obtain and could occur at any point. Finally, marital sexual intercourse was based on the right to sexual fulfilment; it needed no procreative justification, and therefore contraception and abortion were tolerated. ${ }^{65}$

Musallam contrasted these features of Islamic thought with Christianity's repressive approach to sexual intercourse, except as a prerequisite for reproduction, and Christianity's dedication to the idea of permanent, monogamous marriages. Looking at these same features with respect to infertility and marriage law, one can see that, in a Christian framework, one of the tragedies of childlessness was its seeming permanence and the remarkably few options that were available to a childless Christian couple, due to the restrictions on divorce and

64 The hadith is found in a section on marriage to an impotent man, but the hadith text is ambiguous as to whether this is so in the case in question. Logically, it is doubtful that the man is impotent because the issue seems to hinge upon the question of disclosure rather than consummation. Saīd b. Manșūr (d. 227/843), Sunan (Bombay: Dār al-Salafiyya, 1982) 2:81= no: 2021. 65 B. Musallam, Sex and Society in Islam: Birth Control Before the Nineteenth Century (Cambridge: Cambridge University Press, 1983), 11. 
remarriage. ${ }^{66}$ In some cases the childless couple might be able to enter a religious order, or possibly remarry following the death of one of the spouses, or retroactively annul their marriage on the basis of either impediments or consanguinity, but otherwise they were unlikely to experience a change in their marital status. They could not hope to procreate with someone else or to leave a marriage that was marred by childlessness. Thus the late- $7^{\text {th }}$-century East Syrian bishop of Fārs, İšōbōkt, noted that many people think that the Christian ban on divorce is harsh, especially in cases where, "because of sterility or sickness ... a woman is unable to sleep with her husband, [and] he remains deprived of sons." İšōbōkt acknowledged the sentiment but highlighted that the law's severity was at least egalitarian. For "when a man is taken hold by similar infirmities, a wife is compelled to bear this affliction." ${ }^{67}$ Infertility thus accentuated the inherent rigidity of Christian concepts of marriage, as understood in most Christian communities. ${ }^{68}$ By contrast, due to the very same factors that Musallam outlines, in Islamic societies much of the tragedy associated with childlessness was the very fluidity and precariousness of the childless woman's situation. Infertility highlighted the inherent flexibility, and hence uncertainty, embedded in Islamic marriages.

Two factors in Islamic family law played a particularly significant role in shaping the legal position of infertile couples: easily obtainable divorce and the acceptability of polygamy. Because infertility was acknowledged to have multiple potential causes, including sexual dissatisfaction and incompatibility (as will be seen in chapter four), spouses in childless marriages could hope that a different pairing would be more fruitful. The fact that husbands were legally able to divorce their wives for any or no cause, so long as they had the financial and social wherewithal to do so, meant that a childless wife could hope that her husband would divorce her. For then she would be free to marry someone else with whom she could conceive. A childless wife in that same situation, however,

66 There is a history of Catholics criticizing Middle Eastern Christians for practicing bigamy in order to obtain a child, in spite of their own religious precepts. For an example involving polygamy due to childlessness (after the death of an only child) see A. Jaussen, Coutumes des Arabes au pays de Moab (Paris: V. Lecoffre, 1908), 15-16. See also, J. P. Thompson, Photographic Views of Egypt, Past and Present (Boston: J. P. Jewett, 1856), 139.

67 L. Weitz, "Syriac Christians in the Medieval Islamic World: Law, Family, and Society," (Ph.D. Dissertation: Princeton University, 2013), 258. Cf. V. Garver, "Childbearing and Infancy in the Carolingian World,” Journal of the History of Sexuality 21 (2012), 214.

68 Historians of the medieval Catholic church in Europe have noted that many of the restrictions on the dissolution of marriage became formalized and enforced in a process which began only in the eleventh century and continued through the thirteenth. R. M. Karras, Sexuality in Medieval Europe: Doing Unto Others (New York: Routledge, 2005), 62, 68. 
could just as easily fear that her husband would divorce her and marry another woman, leaving his childless divorcée without long-term support.

The existence of the institution of polygamy similarly meant that a childless wife could hope that her husband would not divorce her, but would rather keep her and supplement her with a more fertile spouse. ${ }^{69}$ In this way, polygamy could blunt the impact of the religious duty to produce children, for a man could hope to fulfil that requirement through some of his marriages and not through others. $^{70}$ This, of course, was true of the Prophet Muhammad himself. Equally, a childless wife could fear that her husband would not set her free but would instead have her supplanted with a more fertile wife with whom she would be in (losing) competition.

In addition to divorce and polygamy - institutions explicitly enshrined in Islamic law - a third factor had a substantial role in defining the legal experience of infertile women in their marriages, which I will call the legal distaste for nebulousness. The Sunnī framework for marriage is marked by specific points in the timeline of a marriage. At the beginning of a marriage these include the transferal of the dower, the transferal of the bride to the groom's custody, and the act of consummation. At the dissolution of a marriage, defining points occur when a husband pronounces a formula of repudiation, when a wife renounces a debt owed her or returns a property to her husband, the death of the spouse, the menstrual cycles marking the 'idda waiting period in which both spouses still have financial claims upon each other, and the end of the 'idda when the ties between them have been severed. However, the realization that a marriage will likely not yield children does not occur as a legal assumption at any particular point in an Islamic marriage. Legal sources point this out frequently, particularly when citing the above-mentioned hadith about the 'Umar's "sterile" tax-collector and denying that he could be labeled as such. By contrast, in the Rabbinic Jewish tradition, the ten-year anniversary of the marriage marks a point at which the marriage itself is considered sterile, and there are attendant legal consequences including, theoretically, legally-mandated divorce. ${ }^{71}$

69 See A. Bouhdiba, La Sexualite en Islam, 263. This is not to say that polygamy was the predominant form of marriage.

70 Muḥammad b. Muḥammad al-Ḥaț̣āb, Mawāhib al-jalil (Beirut: Dār al-Fikr, 1992), 3:404.

71 Mishna Yevamot 6:6, and Babylonian Talmud, Yevamot, 65b-66a. See J. Baskin, "Rabbinic Reflections on the Barren Wife," Harvard Theological Review 82 (1989), 101-14. This theoretical requirement was likely not often practiced as such. Cf. Yevamot $64 a$. However, there is some evidence that it could be brought to bear on practical matters when the wife wanted to obtain a divorce from a reluctant husband. A legal question was addressed to Hai Ben Sherira (9391038), the gaon of the Yeshiva of Pumbedita in Iraq: "Regarding one who has lived with his 
No medieval Islamic legal school has a binding test for either male or female fertility, and some medieval jurists note the particular difficulty of establishing the fertility of a sexually inexperienced woman. ${ }^{72}$ For example, in commenting on the hadith, "Marry amiable and fertile women," early Shī'ite writers explain that one predicts the fertility of a virgin based on the fertility of her kinswomen. ${ }^{73}$ This is summarized in the Jawāhir al-kalām:

wife for ten years, which are not continuous, and who was intermittently in a different city and intermittently with her, and by whom she has not had children, is he obligated to divorce her when she asks for a divorce, and to give her her ketubba when she claims "[I want a child] to be a support for my hand and an axe to bury me"? Or does there need to be ten years in which he continuously lived in the same city with her?" Judeo-Arabic fragment in Friedman, Jewish Polygyny in the Middle Ages, $169 \mathrm{ff}$. The requirement is also cited in cases brought by medieval Jewish plaintiff husbands, who wanted to use it to override the clauses in their marriage contracts which stipulated that if they were marry a second wife, they would divorce the first and pay her the money due to her in her ketubba and to return her trousseau. These husbands wanted to either engage in bigamy or to divorce their wives without penalty. The argument was that the clause was invalid if it necessitated them violating the Biblical commandment to be fruitful and multiply. See, for example, Shimon b. Tsemah Duran (d. 1444 in Algiers), Sefer ha-Tashbets (Lemberg: Uri Ze'ev Salat, 1891), §94-95. In those places where the "Ban of Rabbenu Gershom," the $11^{\text {th }}$-century prohibition on both polygamy and unwanted divorce, was enforced there were medieval attempts to override it in cases of infertility. In response, the late $12^{\text {th }} /$ early $13^{\text {th }}$-century German rabbi, Eliezer b. Yoel ha-Levi (Ravyah) wrote that Jewish communities no longer even promote divorce in cases of infertility, let alone use the commandment of being fruitful to override the polygamy ban. He notes that this is due in part to the prevalence of infertility: "We are not at liberty to waive the Ban of the illustrious Rabbenu Gershom, for there are so many unhealthy and barren women, yet no one opens his mouth to complain.” Translation from E. Westreich, "Infertility as Ground for Polygamy in Jewish Law in Italy: Interaction among Legal Traditions at the time of the Renaissance," in Olir - Osservatorio delle libertà ed istituzioni religiose 2 (2003), 12.

72 'Abd al-Karīm Zaydān, al-Mufașșal fī ahkā̄m al-mar'a wa'l-bayt al-Muslim fī al-sharīa al-Islāmìya (Beirut: Mu'assasat al-Risāla, 1994) 6:51.

73 There are many more shī‘i ḥadìths attributed to both Muhammad and 'Alī disparaging marriage to infertile women, as well as providing advice on how to promote fertility. Interestingly, among the modern Druze community which banned polygamy a millennium ago but which does permit divorce, these hadiths have formed the basis for some significant legal disagreements. A. Layish writes: “. . . the Druze Court of Beirut held that proven barrenness of the wife was a shar'i ground for divorce, without the husband being liable (as to the financial consequences), on the strength of two religious-legal rules which provided that 'the supreme purpose of marriage is the production of offspring' and 'a barren wife should be avoided.' A majority of the Lebanese Druze Supreme Court of Appeal also held, in one case in which the wife's barrenness had been proved by medical documents, that the question of offspring was of great importance in a marriage; the husband might invoke barrenness as a ground for dissolution because he has a legitimate right to children 'for the preservation of the name and continuance of the memory [of the family] and the retention of the family property by the agnates in accordance with established tradition'; the court decided by a majority of votes that the husband 
It is said that the combination of [fertility] and virginity occurs in one who is not too young nor menopausal, and who has nothing in her temperament which indicates a tendency to barrenness, such as absence of menstruation. I say, the primary way of knowing whether a virgin is fertile is referring to [the reproductive history of] her kinswomen, her mothers and sisters. $^{74}$

A similar concept of gauging the fertility of virgins based on their kinswomen is found in some late-medieval Sunnī sources such as the Asnā al-mațālib fì sharh Raw ists a specific or formal means of implementing this concept. ${ }^{75}$

\section{Marriage annulment due to infertility and genital defects}

To what extent did Islamic legal theory acknowledge and privilege the desire for children as particularly important in a marriage? And to what extent did it treat the frustration of not being able to reproduce as any different from any other form of marital disappointment? We can begin to answer these questions by examining the sparse legal discussions of whether the prospect of childlessness due to a spouse's infertility can serve as a basis for either a husband or a wife to ask that their marriage be annulled, on the grounds that their spouse's infertility constitutes a defect that cheats the fertile spouse of a marital right. We can also examine legal discussions about injuries to a person's reproductive organs. Within these discussions are debates about whether the law allows someone to be designated as infertile, whether either spouse has a legal right to expect reproduction from a marriage, the sexual rights of spouses to each other and the extent to which those sexual rights can be disentangled from reproductive rights, and the extent to which the loss of one's own reproductive capacities con-

might divorce the wife without this being regarded as arbitrary repudiation entitling her to compensation. On the other hand, the minority of the court held that sterility of the wife (or husband) was not a secular or religious-legal ground for divorce because it did not constitute non-fulfilment of a marital duty the fulfilment of which depends on the will; in fact, in the particular case in question, the wife had done all she could: she had undergone prolonged medical treatment to become fertile." Layish, Marriage, Divorce, and Succession in the Druze Family, 205. 74 Al-Najafī (d. 1266/1855), Jawāhir al-kalām fī sharh Sharā’i al-Islām (Beirut: Mu'assasat alMurtậā al-'Ālamiyya, 1992), 10:360.

75 Zakarīyā ibn Muhammad al-Anșārī (d. 926/1520), Asnā al-mațālib fī sharḥ Raw ạ al-ṭālib (Beirut: Dār al-Kutub al-'Ilmiyya, 2000), Chapter 14, no:263. Al-Bahūtī (d. 1051/1641), Kashshāf alqinā’ (Beirut: Dār al-Fikr, 1982) 5:9. 
stitutes an injury and a harm deserving of a compensation over-and-above the loss of one's capacities for sexual intercourse and pleasure.

The concept of marital defects and annulment can only be understood in the context of the two far more common ways of ending a marriage in Islamic law. These means of dissolving a marriage are: țalāq (male-initiated repudiation) and $k_{h u l}$ (in which the wife buys herself out of the marriage). Unlike in Christian ecclesiastical law, there was no Islamic legal case in which annulment was the only option a couple had for ending a marriage. In all cases a husband could legally choose to end a marriage via talāq rather than annulment, since male-initiated divorce did not require any grounds whatsoever. And a wife could seek out a khul' arrangement to end her marriage, although her power was circumscribed to a greater extent than her husband's. Annulment was thus a lesser-used means of ending a marriage, one subset of which is known as tafriq lil-'ayb (separation due to defect). ${ }^{76}$ This form of annulment is significant for our purposes because medieval discussions about which defects ought to serve as grounds for annulment provide insights into what jurists believed were the minimum expectations of marriage, and sometimes these discussions suggest when legal understandings conflicted with other social or cultural expectations.

Annulment was established by the pronouncement of a judge, rather than the couple. While its use was not common, since it could be invoked in only very few circumstances, there were particular cases in which annulment had practical advantages over the more usual forms of divorce. Repudiation, talāq, was a husband's privilege that had few intrinsic limits but did burden him with potentially heavy financial obligations. These included the support due to the wife during the 'idda (the waiting period that follows a divorce, usually calculated as three menstrual periods), the repayment of the delayed, outstanding portion of the mahr (i.e. the dower paid by the groom to the bride as part of a marriage contract, often in an initial and a later installment) and, in some communities, the giving of a mut' $a$, a "divorce gift." However, if the marriage ended through khul' rather than talāq, the wife, with her husband's consent, bought herself out of the marriage by either forfeiting the money the husband already owed her or otherwise compensating her husband. From a husband's perspective, a khul' divorce had some financial advantages and it is thought, for that rea-

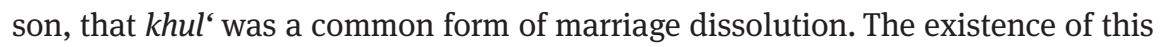
wife-initiated form of divorce was potentially empowering to a wife, but it also created a perverse incentive that could harm her. It could motivate a husband

76 Other grounds for annulment included the discovery that the marriage was illicit, e.g. due to incestuous kinship or to a wife's previous marriage having never properly ended. 
not to offer talāq even if the marriage was an unhappy one because, if the husband could pressure his wife into officially initiating the end of the marriage, he stood to save himself money. ${ }^{77}$ Thus, while the costs of talāq often served as a measure of protection against unwanted divorce, and khul' often served as a means for a woman to assert her independence, these factors also set up an opportunity for potential exploitation. ${ }^{78}$ These concerns made annulment a potentially useful way to end the marriage. From the perspective of a husband, if he could obtain an annulment, he could potentially avoid paying for the maintenance of his former wife during the idda waiting period that followed a divorce. ${ }^{79}$ He could also avoid paying a divorce gift ${ }^{80}$ and possibly (although not usually) he could also avoid paying the delayed portion of the mahr. ${ }^{81}$ From

77 Rapoport, Marriage, Money, and Divorce, 72.

78 E.g. Ibn Rushd al-jadd was asked about a man who consummated marriage with his virgin wife and then, for the next eleven months, "harmed her" in a way which insults women, which Ibn Rushd understands to mean that he did not have sexual relations with her since the consummation. The wife "cannot stand him" and the man refuses to divorce her unless she gives him everything she owns. Ibn Rushd tells the court to warn the man that he has one year to have relations with his wife and if he does not by the end of that time, the court will end the marriage by decree and the wife will owe the husband nothing. Ibn Rushd, Fatāwā Ibn Rushd, 1:185. A similar form of extortion is mentioned in another fatwa , but in that case the wife capitulates to the demand and then sues afterward. Ibid., 2:952. Cf. al-Wansharīsī, al-Mi'yār al-mu'rib, 4:141. The Shāfi'ì jurist Ḥusayn ibn Muhammad al-Marwarrūdhī (d. 462/1069) responds to a case where a woman whose husband never paid the mahr initiates a khul divorce, paying a sum twice as much as the mahr to get out of the marriage. She then attempts to have the marriage retroactively annulled so as to recuperate the money she paid, but the jurist rules against her. See al-Marwarrūdhī, Fatāwā al-qāḍ̄ Ḥusayn ibn Muhammad al-Marwarrūdhī (Amman: Dār al-Fath, 2010), 325. F. Zarinebaf-Shahr writing about Hanafĩ court cases in $17^{\text {th }}$-century Ottoman Istanbul writes that "often, in order to retain the mehr, men forced their wives to initiate divorce" and provides examples of ex-wives (successfully) attempting to retroactively sue for the exploitation. F. Zarinebaf-Shahr, "Women, Law, and Imperial Justice in Ottoman Istanbul in the Late Seventeenth Century" in Women, the Family, and Divorce Laws in Islamic History, ed. Amira El Azhary Sonbol (Syracuse: Syracuse University Press, 1996), 92.

79 Al-Haytamī, Tuhfat al-muhtāj fī sharh al-minhāj in Hawāshī al-Sharawānī wa-Ibn-Qāsim al'Abbādī 'alā tuhfat al-muḥtāj bi-sharḥ al-minhāj li-Ibn Ḥajar al-Haytamī (Beirut: Dār Iḥyā' al-Turàth al-‘Arabī, 1988), 8:229.

$80 \mathrm{Mut}^{\prime} \mathrm{a}$. This was not always a practical component of Islamic divorce. See Y. Rapoport, "Matrimonial Gifts in Early Islamic Egypt," Islamic Law and Society 7.1 (2000), 18-21 and D. Little, "A Fourteenth-Century Jerusalem Court Record of a Divorce Hearing: A Case Study" in Mamluks and Ottomans: Studies in Honour of Michael Winter, ed. D.J. Wasserstein and A. Ayalon (London: Routledge, 2006), 66-85.

81 Consider, for example, the above-mentioned case from the Druze Court of Beirut in Layish, Marriage, Divorce and Succession in the Druze Family, 205. See also Ibn Ḥazm, al-Muhalla (Cairo: Idārat al-Ṭibā‘a al-Munīriyya, 1928), 10:112-114, which discusses partial restitution of the șadāq 
the perspective of a wife seeking to end her marriage, a key advantage of an annulment over other types of marriage dissolution was that she could use it to circumvent a husband who was reluctant to set her free, or who was trying to pressure her into a financially exploitative khul $^{\text {' divorce. }}{ }^{82}$

Jurists identified only a few defects which could serve as legitimate grounds for annulment. Some jurists drew an analogy between marriage contracts and sales contracts and argued that the same (or similar) circumstances that would nullify a sale would also nullify a marriage. Others maintained that only those specific circumstances mentioned in hadiths about marriage annulment could justify such a step. However, regardless of which avenue the jurists pursued, there was a marked tendency to limit the extent to which spousal defects could serve as grounds for annulment. This tendency is remarked upon by the Cordoban jurist and philosopher Ibn Rushd (d. 595/1198) who explained that while contracts of sale and contracts of marriage are similar up until the point of the consummation of the marriage, there are significant differences when defects are found after consummation. Moreover, he wrote, whereas in a sale any defect may be grounds to rescind the contract, there exists a "unanimity of the Muslims on the point that not every defect can lead to the nullification of marriage." 83 The physical and physiological defects most commonly recognized as grounds for annulment were leprosy, elephantiasis, insanity and, most importantly for our purposes, missing or abnormal genital organs.

In the premodern period almost all Sunnì legal discussions of whether infertility is a defect - one which constitutes grounds for the non-sterile spouse to have the marriage nullified - have a uniform conclusion that extends across the legal schools: female infertility is not considered to be such a condition. ${ }^{84}$ There is slightly more debate as to whether that is true for infertile husbands married to potentially fertile wives, with Ibn Taymiyya (d. 728/1328) representing

to the husband. The $5^{\text {th }} / 11^{\text {th }}$-century Shāfi'ī jurist al-Marwarrūdhī rules that under particular circumstances the husband would not pay the mahr. Al-Marwarrūdhī, Fatāwā, 323.

82 The Mālikī treatise al-Nawādir wa'l-ziyādāt includes a chapter on husbands who become aware of a defect in their ex-wives following a țalā $q$ divorce and attempt to retroactively convert it into an annulment, and on wives who become aware of a defect in their ex-husbands following a khul' divorce and attempt to do the same thing. Ibn Abī Zayd al-Qayrawānī, Kitāb al-Nawādir wa'l-ziyādāt 4:36.

83 Ibn Rushd, Bidāyat al-mujtahid (Cairo: Dār al-Salām, 1995), 3:1348. Translation from Imran Ahsan Khan Nyazee, The Distinguished Jurist's Primer: A Translation of Bidāyat Al-Mujtahid (Reading: Garnet, 2000), 2:59.

84 al-Buhūtī, Sharh muntahā al-irādāt (Beirut: Dār ‘Ālam al-Kutub, 1993), 2:678. 
the minority medieval opinion that a woman may have a legal right to procreative sex. ${ }^{85}$

\section{Statements in favor of permitting khiyār (spouse's choice to pursue annulment) in cases of infertility}

Arguments in favor of including infertility among the list of defects permitting a spouse to exercise the choice (khiyār) to have the marriage annulled are quite rare in Sunnī legal literature. The above-mentioned instruction from "Umar $b$. al-Khațāa to the sterile man to "inform her, then give her the choice" is widely cited, but it is then almost uniformly circumvented using the argument that is impossible to determine with certainty that a man really is sterile. Among the exceptions to this rule is Hasan al-Bașrī (d. 110/728), who is reported to have held the view that infertility in either spouse is grounds for annulment if the non-infertile spouse so desires. His opinion is cited by the Hanbali jurist Ibn Qudāma (d. 620/1223) as follows, "If one [spouse] has found the other to be sterile, [the non-sterile spouse] is given the choice." 86

The Shāfíī jurist al-Māwardī (d. 450/1058) states that there is an opinion within the school that a woman has a right to khiyār in the case of a husband who is able to have intercourse, but who lacks testicles, "because he is missing something without which there cannot be offspring." ${ }^{87}$ While it is common among jurists to view genital defects as a legitimate reason for annulment on the grounds that such defects interfere with sexual intercourse, al-Māwardī's phrasing, which emphasizes offspring rather than intercourse, is unusual.

Ibn Taymiyya makes a novel argument for considering infertility, at least male infertility, as grounds for annulment. Rather than rooting the argument in definitions of defect, he draws a legal analogy between sterility and contraception: "If a husband is proven to be sterile, we rule by analogy that the woman has [the right of] choice, since she has a right to a child. It is for this reason that we say one cannot practice coitus interruptus with a free woman with-

85 This generalization about the literature is also confirmed in Vardit Rispler-Chaim, "Ḥasan Murād Mannā: Childbearing and the Rights of a Wife,” 95-6. However, in 1995, a Saudi muftī, citing 'Umar's statement about the 'aqim, ruled that the wife of an infertile man could have her marriage annulled on the grounds that women marry for the purpose of having children. V. Rispler-Chaim, Disability in Islamic Law (Dordrecht: Springer, 2010), 61.

86 Ibn Qudāma, al-Mughnī, 10:59.

87 al-Māwardī, Kitāb al-ḥāwĩ al-kabīr (Beirut: Dar al-Kutub al-'Ilmiyya, 1999) 9:340. 
out her permission." 88 Ibn Taymiyya's argument is based on the premise that there is a consensus (within the Hanbali school) that it is not permitted for a man to practice coitus interruptus without his wife's consent. Building upon this premise, he argues that the reason that unilateral coitus interruptus is not permitted is because a free woman has a right to a child, and contraception would violate that right. Since a husband's sterility would also violate that right, logically it too may not be imposed upon a wife without her consent. Ibn Taymiyya's argument is not unproblematic; other jurists who also believe that a man has to obtain his wife's consent before practicing withdrawal argue that the legal right being violated is her right "that he ejaculate in her when having sexual relations with her," 89 but that is a right to sexual fulfilment rather than a right to procreative sex. Ibn Taymiyya's understanding of the legal rights underlying the laws of consent and coitus interruptus is unusual but not unique. It is also found in the writing of the Hanafī jurist al-Kāsānī. The latter says that it is disliked for coitus interruptus to be practiced without the woman's consent, "because sex culminating in ejaculation is the way of getting a child, and she has a right to a child."90 Within Ibn Taymiyya's own school, Ibn Qudāma agrees with him with regard to contraception though not with regard to actual sterility. I.e. a wife has a right to demand procreative sex rather than coitus interruptus, because she may want a child, but he does not extend that logic so as to support the notion that a wife may demand an annulment of her marriage to a sterile man.

Ibn Qayyim al-Jawziyya, Ibn Taymiyya's disciple, provides a long and detailed list of defects which are grounds for khiyār and that list does not explicitly include infertility. However, he makes an unusual argument that could be read as implicitly in favor of viewing infertility as a defect. After concluding his list he writes:

It is preposterous to limit defects to two, six, seven, or eight to the exclusion of those which are inferred from them or are equivalent to them, such as the blind, the mute, the deaf and the woman whose hands and legs have been amputated either one or both. . . . The Commander of the Faithful, 'Umar b. al-Khatțāb, told someone who had married a woman despite not being able to sire children: "Inform her that you are sterile and give her the choice." What would he ['Umar] say about defects which for her are complete, rather than partial? The analogy is this: that for every defect which repels the other spouse - and as a result of which mercy and benevolence, which are goals of marriage, cannot be

88 Ibn Taymiyya, Fatāwā al-kubrā, 5:464.

89 Aḥmad b. Muhammad al-Ṭahāwī, Sharh ma'ānī al-āthār (Beirut: 'Ālam al-Kutub, 1994), 2:30-31.

90 Al-Kāsānī, Badā’’‘ al-ṣanā’i‘ (Beirut: Dār al-Kutub al-’Ilmiyya, 1986), 2:334. 
attained - khiyār is mandated. This is inferred from [the law of] sales, just as the conditions which are stipulated in marriages are based on the fulfilment of the conditions of sales. God and His Prophet did not subject one who is misled and deceived to the one who misled and deceived them. ${ }^{91}$

Ibn al-Qayyim seems to be using the example of male sterility as the initial premise in an a minori ad maius argument, i.e. if "Umar mandates khiyār in the case of sterility which is a "partial" defect, all the more so must khiyār be mandated in cases of a "complete" defect, such as blindness, muteness, etc. However, nowhere does he explicitly state or prove the initial "minor" premise implied here; he does not include sterility in the formal list of defects which have scriptural standing. Instead, he argues that there are many defects in addition to scriptural ones which could contravene the goals of marriage and thus may serve as grounds for annulment, and sterility falls into at least one those categories.

\section{Objections to including infertility among the grounds for annulment}

There are three different, frequently mentioned objections to including infertility as grounds for annulment: first, the (disputable) claim that it is not mentioned in any revealed text (nașs) as grounds for annulment, and only those specifically revealed grounds are acceptable. Second, that logically the only acceptable grounds for annulment are ones that bar sexual intercourse and infertility does not do that. And third, that it is impossible to know for certain whether someone is sterile and so no one, particularly no man, can be labeled as such.

\section{Ḥanbalī views}

Of all the legal schools, the Hanbalis permit marriage nullification for the most diverse set of reasons. They grant the choice to pursue annulment to both husbands and wives of spouses who suffer from insanity, leprosy, and elephantiasis; to wives of impotent ${ }^{92}$ or castrated men or those without functioning testicles; ${ }^{93}$

91 Ibn Qayyim al-Jawziyya, Zād al-ma'ād, 5:182.

92 There is some disagreement among H̦anbaliss regarding the man who is able to consummate the marriage once but then becomes impotent, see Spectorsky, Chapters on Marriage and Divorce, 113. The two opinions are either that the wife has no grounds to annul the marriage, or that the husband is given one year to prove himself able to have intercourse. If he does not have sexual intercourse in that time, there appears to be a judicially mandated taläq: the wife is given the full dower and must then begin her 'idda period. 
and to husbands of women who suffer from 'afl, qarn, fatq, or bahr, which refer to abnormalities of the female genitals. ${ }^{94}$ Such genital abnormalities will be addressed later in this chapter. Ibn Qayyim al-Jawziyya describes the contrast between the schools of law thus:

Dāwūd (d. 270/884), Ibn Ḥazm (d. 456/1064), and those who agree with them say that there is no nullification at all. ${ }^{95}$ Abū Hanifa says that there is no nullification except for castration and impotence. Al-Shāfi'ī and Mālik say: insanity, leprosy, elephantiasis, ${ }^{96}$ vaginal blockage, castration, and impotence are bases for annulment. Imām Ahmad [ibn Ḥanbal] added to [al-Shāfi'ī and Mālik's grounds for annulment]: also if the woman has been ruptured such that [the flesh] between the two orifices has been torn. According to his colleagues: also if there is a putrescence of the vagina and the mouth, ${ }^{97}$ or if the openings for urine and semen in the vagina have been torn, or if there is an oozing wound in them, as well as hemorrhoids and fistulae. [They also include the conditions of] istihâa da (constant menstruation), leaking of urine and such, lack of testicles, tuberculosis of the testicles, and waj', i.e. one whose testicles are crushed, and if either [spouse] is a khuntha (intersex) in appearance. ${ }^{98}$

In the Hanbali school, this list of defects is arrived at through the logic of sales/ returns and the logic of the goals of marriage, rather than being understood simply as a matter of divine decree. ${ }^{99}$ As to whether this list is an exhaustive one, there exists a difference of opinion between Ibn Qayyim al-Jawziyya and Ibn Taymiyya on the one side, and Ibn Qudāma on the other. Ibn al-Qayyim argues that these grounds for annulment are examples illustrating a general principle that, when the purpose of marriage is itself thwarted, the non-defective spouse may choose to end the marriage through annulment. Thus, in his view, there could be grounds beyond these examples. By contrast, Ibn Qudāma uses the same

93 Manșūr b. Yūnus al-Buhūtī, Sharh muntahā al-irādāt, 2:676.

94 Ibn Qudāma, al-Mughnī, 6:651 and al-Buhūtī, Sharh muntahā al-irādāt, 3:86.

95 These jurists are associated with the Zāhirī school of Islamic law. Ibn Qayyim al-Jawziyya quotes Ibn Hazm's tongue-in-cheek argument that if the marriage contract describes the wife as healthy, and she is found to have any medical problem whatsoever, including infertility, he has technically not married her at all but rather some theoretically healthy person. He does not have the option of remaining married or dissolving the marriage because they are not spouses. Ibn Ḥazm, al-Muhallā (Beirut: Maktab al-tijārī lil-tibā‘a, 1969) 1:115.

96 See Rispler-Chaim, Disability in Islamic Law, 64, and R. Shaham. The Expert Witness in Islamic Courts (Chicago: University of Chicago Press, 2010), 42.

97 There seems to be some disagreement in the commentary tradition as to whether this is the literal mouth or the vaginal orifice or both.

98 Ibn Qayyim al-Jawziyya, Zād al-ma'ād, 5:165.

99 This is the argument in the Mughnī, in the Zād al-ma'ād, and Sharh muntahā al-irāāatt. 
starting point (that the above-listed defects are based on the logic of threats to the purpose of marriage) to come to the opposite conclusion:

Any defect outside of these does not thwart the purpose of the marriage bond, which is sexual intercourse, as opposed to the various defects which are included in these. If one was to say, "leprosy and skin lesions do not thwart sexual intercourse," we would say: "in fact it does thwart it, because it produces an aversion which altogether prevents him from approaching, for he fears that he and his offspring will contract it." So too, one is afraid of an attack from a madman, and that serves as a palpable barrier [to intercourse]. ${ }^{100}$

Ibn Qudāma's argument assumes that the purpose of marriage is sexual intercourse, and that all the canonical grounds listed for khiyār are in fact related to the ability to engage to intercourse. In Ibn Qudāma's view, there is no other purpose of marriage which, if thwarted, could be addressed through annulment. Since infertile people may still engage in sexual intercourse, infertility cannot be considered to be among the conditions that thwart the purpose of marriage and thus cannot serve as the basis for annulment.

In a similar vein, al-Buhūtī (d. 1051/1641) argues that infertility should be rejected from the list of legal defects because it does not preclude sexual enjoyment. He writes:

Regarding defects other than those previously mentioned, none of these are grounds for either one of the spouses to exercise khiyār. For example, one-eyedness, lameness, lacking a hand or a foot, blindness, muteness, deafness, baldness, or one of them being infertile or menopausal [none of these may serve as grounds for nullification] . . . because none of these prevent sexual pleasure or threaten to infect [the other spouse]. ${ }^{101}$

A different objection raised within the Hanbali school against infertility being included among grounds for nullifying a marriage is that it is impossible to prove for certain that someone is infertile. In spite of the tradition in which 'Umar instructs a sterile man to divorce his wife and give her the choice of whether or not to re-enter the marriage, Ibn Qudāma says that it is impossible to categorically state that someone will never produce children.

We do not know of any scholar who disagrees with [the view that infertility should not count] other than Hasan [al-Bașrī] who said, "If one found the other to be infertile, they give them a choice.” Ahmad [Ibn Hanbal] tended to explain his words saying, "Perhaps his wife would like a child." But this is at the beginning of the marriage, so on what basis could it be nullified when [infertility] itself cannot be proven? One might prove it

100 Ibn Qudāma, al-Mughnī, 10:56.

101 al-Buhūtī, Sharḥ muntahā al-irādāt, 2:678. 
on the basis of menopause but, on the other hand, it is known that there are men who do not produce offspring when they are young, but then have offspring when they are old. ${ }^{102}$

In summary, there is a minority opinion within the Hanbali school that a diagnosis of infertility, or at least male infertility, can serve as grounds for annulling marriage. However, the majority view is that infertility in either husbands or wives cannot be used in this way. However, among those espousing such a view, there is a disagreement as to whether infertility is excluded on the grounds that it is irrelevant since it does not preclude engaging in sexual relations, or whether it is excluded because one cannot actually label a spouse as infertile in the first place.

\section{Ḥanafī views}

Of the four main Sunnī legal schools, the Hanafĩ one has the most restricted definition of marital defects. Hanafī discussions of 'ayb (defect) and faskh (nullification) are unique in that a wife's defects are never grounds for nullification. Instead, a husband has only one option for ending his marriage: traditional divorce. A wife, by contrast, may be able to have her marriage annulled if her husband is defective. However, a husband's defectiveness is determined solely on the basis of whether he has ever succeeded in penetrating his wife anytime during the marriage. No other aspects of his physical or mental state enter into the matter. The position is summarized by al-Kāsānī (d. 587/1191).

With regard to the circumstances in which [a wife is entitled to] a choice [to have her marriage nullified]: the first and foremost consideration is whether he has had intercourse with this woman in this marriage. To such an extent is this the case that, if he had intercourse with her only once, then the choice to exercise that right has been passed up and no longer exists. $^{103}$

If the husband lacks a penis, the nullification can take place immediately. If a woman claims that her husband is impotent, the husband may have up to one year to attempt to penetrate his wife after the complaint is brought to the court's attention. ${ }^{104}$ If a woman finds herself married to a man whose testicles have been

102 Ibn Qudāma, al-Mughnī, 10:59-60.

103 Al-Kāsānī, Badāił‘ al-șanā'i’, 2:325. Zaydān, al-Mufașșal fī ahkkām al-mar'a wa'l-bayt al-Muslim fĩ al-sharīa al-Islāmiyya, 9:24.

104 In al-Fatāwā al-siräjiyya the text specifies that this is a lunar year, eleven days shorter than a solar year. al-Ūshī, Sirāj al-Dīn Abū Muhammad 'Alī ibn 'Uthmān, al-Fatāwā al-sirājiyya (Lenasia, South Africa: Dār al-uulūm Zakariyyā, 2011), 205. 
severed but who retains a penis (khașiyy) the case is treated as one of impotence, on the grounds that such a man may yet achieve an erection and penetrate his wife. This last scenario is significant because it allows us to differentiate between sterility and impotence. The man without functioning testicles is (in the jurists' view) necessarily permanently sterile but not necessarily permanently impotent. If he is able to overcome his impotence and penetrate his wife, he possesses no legal defect. The fact that he is still sterile has no legal consequence.

Even though Hanafī jurists often rule that a wife has a right to insist upon sex that is not curtailed by coitus interruptus, they do not make the argument that she has a right procreation. Usually, it appears that jurists understand "her right to obligate him to ejaculate into her"105 as a right to intercourse itself, nothing more. Al-Kāsānī, by contrast argues that a wife's rights are not limited to sex. She has a right to the kind of sex that would allow her to conceive. "It is disliked for a husband to engage in 'azl (coitus interruptus) with his free wife without her consent, because sex culminating in ejaculation is the way of getting a child, and she has a right to a child. With ' $a z$, the [conception of a] child is thwarted and therefore her right is thwarted." 106 However, even if her husband ignores her prerogatives by practicing non-procreative sex, his behavior is categorized as either permitted or disliked - it is not forbidden and it certainly does not serve as grounds for nullifying a marriage. Moreover, al-Kāsānī never takes the next logical step Ibn Taymiyya articulates; that is to say, he does not argue that a woman may choose to request an annulment of a marriage to a sterile husband.

\section{Shāfi‘̄i views}

Al-Shāfíī argues that a man cannot know for certain that he is sterile. He therefore denies that the frequently-mentioned case of the sterile man being ordered to give his wife a means to exit the marriage has any practical application.

If he married her and said, 'I am infertile,' or he said nothing about it until the contract had been completed and then he acknowledged it, she would still not have a choice. That is because he himself cannot know that he is infertile until he dies, because a man may be slow to have a child when he is young and yet he will have progeny when he is old. She does not have a right to choose on the basis of progeny. This is because the right to choose is reserved for loss of the ability to have sex, not the loss of the ability to have progeny." 107

105 Al-Ṭahāwī, Sharh ma'ānī al-āthār, 3:30-31.

106 Al-Kāsānī, Badā’’‘ al-ṣanā’’ 2:334.

107 Al-Shāfi'ì, Kitāb al-umm (Beirut: Dār al-Ma'rifa, 1990), 5:43. 
This view that one cannot consider infertility as a defect because one can never be sure that it will not eventually be overcome is echoed by subsequent Shāfíi jurists such as al-Māwardī, who explicitly extends the argument to the reverse case, when it is the wife who is accused of infertility. Al-Māwardī articulates this position in the context of a discussion about a wife who suffers from ifd $\bar{a}$, a rupture in the genitals which can cause infertility. He writes regarding this injury: "Because he can have complete intercourse - even if she is infertile and cannot have offspring, or even if he, the husband, is sterile and cannot beget children - there is no khiyār for either one of them because this [sterility] is speculative, and perhaps it will end."108 The same conclusion, that neither rupture nor infertility constitutes grounds for annulment, is also articulated by alNawawī. ${ }^{109}$

While this idea that infertility is not a defect because it cannot be proven is repeated frequently, Shāfi'îs also refute the claim that a woman has a right to offspring. This is consistent with the madhhab's view of a husband's decision to engage in coitus interruptus without the wife's permission. ${ }^{110}$ With the exception of al-Shīrāzī (d. 476/1083), the Shāfi'îs permit a husband to engage in this contraceptive practice regardless of his wife's consent, because she has a right to sexual intercourse, not to progeny.

\section{Mālikī views}

The majority Mālikī position regarding what constitutes grounds for annulment is similar to the Hanbali one, with some minor distinctions with respect to specific kinds of defects, such as leprosy and forms of male castration. ${ }^{111}$ There is, however, some disagreement as to whether a woman can ever exercise khiyār after the consummation of a marriage. The topic of female infertility specifically is barely considered in Mālikī texts. In Ibn Abī Zayd al-Qayrawānī’s (d. 386/996) al-Nawādir wa'l-ziyādāt, the matter is dispensed with in one sentence: "As for one who is deceived by an infertile woman who cannot give birth, or a woman who is deceived by a sterile man, neither one of them has a [legal] argu-

108 Al-Māwardī, Al-Ḥāwī, 9:341.

109 Al-Nawawī, Rawḍat al-țālibīn wa-'umdat al-muftìyīn (Beirut: al-Maktab al-Islāmī, 1991), 7:178.

110 Al-Nawawī (d. 676/1227), exceptionally, disapproves of 'azl even with a wife's consent. Abdel Rahim Omran, Family Planning in the Legacy of Islam (Routledge: New York, 1992), 159 ff. 111 Khalīl ibn Isḥāq al-Jundī, Mukhtaṣar (Cairo: Dār al-Ḥadìth, 2005), 1:102 and al-Qarāfī, alDhakhïra (Beirut: Dār al-Gharb al-Islāmī, 1994), 4:419-20. 
ment." 112 Male infertility receives slightly more attention elsewhere. In the $M a$ wähib al-jalil, in the context of a discussion of men's responsibilities when seeking a spouse, the Libyan jurist al-Ḥațāab (d. 954/1547) writes about the extent to which a prospective husband has an obligation to disclose to his prospective spouse his own proclivities toward asceticism with respect to fasting and to sex, especially if fasting leads to diminished sexual capacities or to a diminished ability to earn a living. Turning specifically to the question of procreation, al-Hațțāb writes that a man ought to disclose in advance that he will not or cannot engage in marital sexual relations, but he has no responsibility of disclosure if he simply believes himself to be infertile. The first two situations, i.e. sexual asceticism and diminished earning capacity, are deemed to be harmful to the wife and to jeopardize their marriage, but the prospect of childlessness is not so deemed. ${ }^{113}$

\section{Genital defects, "female impotence," and their relation to infertility}

We have seen that while the jurists consider the possibility that a person might wish to annul their marriage to an infertile spouse, for the most part they ultimately reject the legality of doing so. However, with the exception of the Hanafīs (who reject altogether the notion of husbands annulling marriages on the basis of defects) most jurists do recognize a category of legal defect which is related to female infertility. They recognize defects to women's sexual and reproductive organs as constituting grounds for annulment.

Such defects are described using the following vocabulary:

a) ' $a f l$ : A piece of flesh inside the vagina, resembling a man's scrotal hernia. This may correspond to the biomedical diagnosis of a vaginal prolapse.

b) qarn: A tissue or bone that blocks the vagina. This may correspond to the biomedical diagnosis of a vaginal septum.

c) ratq: Usually this is described as a piece of flesh partially or fully blocking the opening of the vagina, thereby rendering it so narrow that a penis can penetrate only with difficulty or not at all. This seems to correspond to the biomedical diagnosis of an imperforate hymen. It is also sometimes described as a piece of flesh within the cervix which partially or fully blocks

112 al-Qayrawānī, al-Nawādir wa'l-ziyādāt, 532.

113 al-Ḥaț̣āan, Mawāhib al-jalīl 3:404. 
off the uterus. This growth within the cervix may correspond to a number of modern biomedical diagnoses. ${ }^{114}$

d) ifda ${ }^{\prime}$ or fatq: Rupture. This is described in the legal literature as a hole or fistula in the flesh dividing two organs, either the vagina and the rectum, or the vagina and the bladder, such that they are no longer completely separated.

The first three female sexual defects are all treated in the legal literature as being similar. Ibn Qudāma suggests that 'afl, qarn, and ratq be understood as nearly synonymous. ${ }^{115}$ They all refer to a vaginal passage too narrow for normal forms of sexual intercourse due to some blockage. From a medieval standpoint, unlike the male sexual defects (castration and impotence), all four of these female "defects" are adjacent to the traits considered to be desirable in women. The intact hymen is itself understood as an obstruction and as the very symbol of virginity. Similarly, in medieval dictionaries, afḍa means both to deflower a virgin and to "make the woman's two orifices [the rectum and the vagina] one." ${ }^{116}$ According to some Egyptian jurists, ratq was also known as a potential complication associated with female circumcision, a ritual which those jurists generally viewed in a positive light and which was often performed when a girl was on the cusp of marriage. ${ }^{117}$ For example, the Cairene Māliki jurist alQarāfī (d. 684/1285) cites the Sicilian jurist Ibn Yūnus (d. 451/1061), citing the Alexandrian jurist Muhammad ibn al-Mawwāz (d. 281/894), discussing marriage annulment in cases "where the imperforate hymen is caused by circumcision" (al-ratq min al-khitān). ${ }^{118}$

In Arabo-Galenic medical literature, all of the first three conditions were thought to be curable, unlike the non-sexual medical defects that were grounds for annulment, such as insanity or leprosy. ${ }^{119}$ For example, the $4^{\text {th }} / 10^{\text {th }}$-century

114 al-Rāzī, al-Ḥāwī fĩ al-țibb (Beirut: Dar al-Kutub al-'Ilmiyya, 2000) vol. 3, book 9:16. 115 Ibn Qudāma, Mughnī, 10:56.

116 Lane, Arabic-English Lexicon, s.v. f-ḍ-ā. Cf. Al-Fayyūmī, Al-Miṣbāḥ al-munīr fī Gharīb alSharh al-kabīr, s.v. f-d-a-a. Al-Fayyūmī states that it can also refer to a rupture which unifies the vagina with the urethra.

117 J. Berkey, "Circumcision Circumscribed: Female Excision and Cultural Accommodation in the Medieval near East, International Journal of Middle East Studies 28.1 (1996), 30.

118 Al-Qarāfī, al-Dhakhīra, 4:421. Also cited in Ibn Abī Zayd al-Qayrawānī, Kitāb al-Nawādir wa'l-ziyādāt, 4:529. Some modern medical journals have also noted that female circumcision can cause imperforate hymen as well as making it more difficult to identify and more dangerous to treat. E. g. M. Alsammani, "Imperforate Hymen Complicated with Genital Mutilation: A Case Report,” Journal of Clinical Case Reports, 2 (2012), 107.

119 The Mukhtașar Khalil also mentions this, but does not seem to attach any significant legal consequence to this fact. Khalīl ibn Ishạaq al-Jundī, Mukhtașar, 1:103. The relative ease or difficul- 
Andalusian physician and surgeon al-Zahrāwī describes ratq as potentially causing retention of the menses or making intercourse, conception, and delivery difficult, and then he details methods for curing it. Al-Rāzī, writing in $3^{\text {rd }} / 9^{\text {th }}$-century Iraq and Iran, describes much the same thing. Such well-known authorities as Galen, Celsus, Paul of Aegina, al-Majūsī and Ibn Sīnā all wrote on the subject. ${ }^{120}$ To cure ratq, writes al-Zahrāwī, one should instruct a midwife to break through the barrier using either a probe or her fingers or, in extreme cases, a scalpel. AlRāzī suggests the physician use a probe.

Unfortunately, this procedure could very well cause the fourth genital defect which, in some schools, could serve as grounds for annulment. This defect is known as if $d \bar{a}$ ' or fatq, rupture. Outside of legal literature, both terms have a broad spectrum of meaning, with fatq also including non-feminine-specific medical conditions such as hernias, and if $\bar{a} \bar{a}$ ' also referring to the defloration of a virgin. ${ }^{121}$ However, both the terms if $\bar{d} \bar{a}$ ' and fatq, when used in legal discussions of marital defects and injuries, seem to be used interchangeably and refer not to defloration, but to severe injury, usually in the context of rape or early marriage. For example, the Hanbalī jurist Ibn Qudāma glosses the word fatq saying:

ty of treating each of these conditions is discussed by Muhammad ibn 'Abd al-Bāqī al-Zurqāni (d. 1099/1710) in his commentary on the Mukhtașar. Al-Zurqāni, Sharh al-Zurqānī 'alá Mukhtașar Sayyidī Khalīl (Beirut: Dār al-Kutub al-'Ilmiyya, 2002), 3:421.

120 M. S. Spink and G. L. Lewis, Albucasis on Surgery and Instruments (Berkeley: University of California Press, 1973), 458-59. In Ibn Sīnā, Qānūn fĩ al-țibb (Būlāq: al-Mațba‘a al-Āmira, 1878)

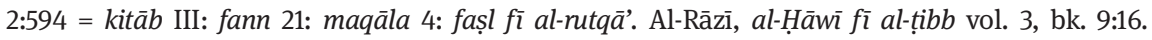
The Mālikī jurist Asbagh ibn al-Faraj in Șa'īd (d. 225/840), also mentions the possibility of curing the ratq. Cited in al-Qayrawānī, Kitāb al-nawādir wa'l-ziyādāt, 4:529. There it mentions the treatment taking anywhere between several months and up to a year. Cf. al-Majusī, Kāmil, 488.

121 In medical literature, futuq can refer to a variety of injuries in which the muscular wall of a bodily cavity is split or perforated or compromised, such that something outside protrudes through it, e.g. a hernia. It can also mean something that was closed or narrow and has been split open. For example, when clouds in the sky are parted or split asunder so that the sun shines through. With regard to a woman, the Lisān al-'arab defines fatqu' as "a woman with a widened vagina, the opposite of a ratqā', " But the same dictionary also includes the definition that appears in legal literature a that is: fatq $\bar{a}$ " "a woman whose two exits [vagina and rectum] have become one." If $d \bar{a}$ ' too seems to have a wider spectrum of meaning outside legal writings, including defloration of a virgin. The definition in the Lisān al-'arab that corresponds to medieval legal usage is this: "A woman who is mufḍa: one whose two exits have become connected ... as a result of coitus." 
He said, regarding one who has sexual relations with his minor wife $\mathrm{e}^{122}$ and ruptures her, he owes one-third of the diyya. [I.e. he must pay one third of the sum he would pay for manslaughter.]

Meaning of $f a t q$ (rupture): a perforation of [the barrier] between the passages for urine and semen. And it is also said: instead, it means a perforation of [the barrier] between the vagina and rectum. But that [second definition] is unlikely, because it is unlikely that the wall between the two spaces would be eliminated through sex, for this wall is strong and tough. ${ }^{123}$

The term if $\mathbf{a} \bar{a}$ ' when used in hadith and legal literature with reference to compensation for injury or genital defects also seems to refer to a similarly severe condition with disastrous repercussions. ${ }^{124}$ In an early hadith collection the injury is described as one that may result in an inability to maintain a pregnancy or retain urinary and fecal continence.

Zayd b. Thābit said, "Regarding a woman whose husband ruptured her: If fertility and both forms of continence are retained, a third of the diyya [is owed] for it. If fertility and both forms of continence are not retained, a full diyya [is owed] for it. ${ }^{125}$

The full diyya, or "bloodwit," refers to the amount of compensation owed to a victim's family in case of manslaughter. Compensation for non-fatal injuries is calculated as a fraction of the diyya and is paid to the living victim.

Regarding a man who was spurned by a woman. He then ruptured her. 'Umar imposed the hadd punishment upon him and [further] penalized him with a sum of one third of her diyya. ${ }^{126}$

122 Medieval Islamic legal sources mention the dangers of intercourse, but not of childbirth, for young brides. By contrast, Jewish law in the late antique and medieval period seems to take into account the dangers of birth, but not of intercourse, for young brides. Hence it mandates the use of contraceptives for intercourse (but not abstinence) with girls. B.T. Yevamot 12b. Some Ḥanafī jurists also mention the concern that women given in marriage be robust enough to "tolerate the pain of circumcision,” e. g. Ibn Nujaym (d. 970/1563) in his Bahr al-ra’̄̃ $q$ and Maḥmūd ibn Aḥmad al-Marghīnānī, (d. 1220) in his Muhịt al-burhānī fĩ al-fiqh al-Nu'mānī (Beirut: Dār Iḥyā' al-Turāth al-'Arabī, 2003), 3:163.

123 Ibn Qudāma, al-Mughnī, 12:169-70.

124 It is possible that a somewhat less violent but similar injury is being described in al-Wansharīsī, Mícyār al-mu'rib 3:234-5. It tells of a man who, in the course of consummating marriage to his virgin bride, did something which made her wet the bed, and she continues to do so nightly. He wishes to return her to her father, who refuses on the grounds that she had no such condition before.

125 'Abd al-Razzāq, Muṣannaf (Beirut: Dār al-Kutub al-'Ilmiyya, 2000), 9:262 = no. 17667.

126 Musannaf Ibn Abī Shayba \#27325. 
Al-Ṣādiq was asked about a man who came upon a girl and ruptured her such that since then she excreted in this organ. She could not give birth. ${ }^{127}$

He beat a woman and ruptured her (afḍahhā): meaning, he made the orifice from where her urine comes out and the orifice where her menses come out one; or [the orifices of] her menses and excrement one. This coitus was like a beating. Regardless of whether this is an unrelated woman who fights against it, or a wife whom he tears up during coitus, if she is rendered incontinent by it [he pays a penalty]. ${ }^{128}$

Regarding if $\mathbf{a} \bar{a}$ ' (rupture), which is when the barrier between where the penis enters and where the urine exits is punctured . . . he is able to have complete intercourse, even if she is infertile and cannot have offspring. ${ }^{129}$

There is no khiyār as a result of either him or her being sterile, nor for her being mufda $\bar{a}$. If $q \vec{a} \vec{a}^{\prime}$ is the elimination of that which is between where the urine exits and where the penis enters. ${ }^{130}$

These descriptions of injuries most closely resemble the conditions known in modern biomedicine as vesico-vaginal fistulae and recto-vaginal fistulae, in which there is a hole in the tissue separating either the vagina from the urinary tract, or the vagina from the rectum, such that excreta leak into the vagina. In modern medical literature, gynecological fistulae are most often discussed as a common obstetrical complication in the developing world, particularly among women whose bodies are too underdeveloped to healthily deliver children. ${ }^{131}$ It is less frequently associated with sexual trauma in modern medical literature, ${ }^{132}$ although it has received some attention from advocacy groups publicizing the problem of wartime rape. ${ }^{133}$ Until the advent of modern surgery,

127 Muḥammad al-Najafī, Jawāhir al-kalām, 15:450.

128 Ibn 'Ābidīn, Radd al-muhtār 'alā al-Durr al-mukhtār (Beirut: Dār al-Kutub, 1994), 10:221. 129 al-Māwardī, Kitāb al-ḥāwī al-kabīr, 9:341.

130 Al-Nawawī, Raw ḍat al-țālibīn, 7:176.

131 For information about vesico-vaginal fistulae and recto-vaginal fistulae, see L. Wall, "Dead Mothers and Injured Wives: The Social Context of Maternal Morbidity and Mortality among the Hausa of Northern Nigeria," Studies in Family Planning 29 (1998), 341-59.

132 For an exception, see: M. Muleta and G. Williams, "Postcoital Injuries Treated at the Addis Ababa Fistula Hospital, 1991-97,” Lancet 354, no. 9195 (1999), 2051-2 and A. M. Abasiattai et al., “Vaginal Injuries During Coitus in Calabar: A 10 Year Review,” Nigerian Postgraduate Medical Journal 12.2 (2005), 12:140 - 4.

133 E. g., A. Longombe et al., "Fistula and Traumatic Genital Injury from Sexual Violence in a Conflict Setting in Eastern Congo: Case Studies,” Reproductive Health Matters 16.31 (2008), $132-14$. 
fistulae were largely incurable, always debilitating, but usually non-fatal. ${ }^{134}$ In the $11^{\text {th }} / 17^{\text {th }}$-century Durr al-mukhtār and in its $12^{\text {th }} / 18^{\text {th }}$-century commentary, the condition is described as being so severe as to make the possibility of sexual intercourse so remote that rules of gender segregation between unrelated members of the opposite sex may no longer apply. It has been argued that ifd $\bar{a}$ ' and fatq sometimes refer to fourth-degree perineal tearing, which is when the skin and muscle between the vagina and anal sphincter, and the sphincter itself, are torn, usually in the course of childbirth. ${ }^{135}$ In modern medical diagnosis, the most salient feature of such injuries is fecal incontinence. Unlike these modern diagnoses, however, the injuries known as ifda $\bar{a}$ ' and fatq are described by medieval jurists as being the result of sexual intercourse, not of childbirth. If $\bar{a}_{\bar{a}}$ ' is also a term used in the legal literature to indicate rape. ${ }^{136}$ Some legal works also mention that ifd $\bar{a}$ ' can occur by means of an instrument, such as a stone or tool, but even so it is still understood as a sexual act. ${ }^{137}$

All four of the genital-related defects mentioned in the legal sources correlate very strongly with physical immaturity. Moreover, the interventions used to attempt to cure these defects could lead to long-term infertility. I.e. treating a woman who has the defect of having a narrow or obstructed vaginal passage ( ratq) may lead to a woman becoming a fatqa ' whose vaginal wall has been damaged resulting in a fistula. Intriguingly, there is some evidence from Catholic Spain that such genital defects were considered to be a form of "female impotence," and that accusations of this sort of female impotence sometimes served as a legal cover for accusations of infertility since, in Catholicism too, impotence was grounds for annulment whereas infertility was not. This may or may not be true in the Islamic context, given that in Islam there were more avenues available for ending a marriage.

134 On the social effects of fistulae in a modern community see A. I. Islam and A. Begum, "A Psycho-Social Study on Genito-Urinary Fistula.” Bangladesh Medical Research Council Bulletin 18.2 (1992):82-94

135 Hina Azam translates the injury, in the context of violent sexual assault, as "perineal tearing." However perineal tearing is a term with a wide valence (i.e. the injury can be superficial or more serious) but it is primarily used in regard to the relatively minor injuries to the surface of the body that often coincide with healthy childbirth, whereas in the context of medieval Islamic claims for damages, it refers to an injury that primary effects internal organs and that may result in multiple forms of incontinence. H. Azam, Sexual Violation in Islamic Law (New York: Cambridge University Press, 2015), 100.

136 For the use of the term to indicate rape see, D. Serrano, "Rape in Maliki Legal Doctrine and Practice," Hawwa 5 (2007), 166-207, esp. 167..

137 E.g. Al-Kāsānī, Badā’i‘ al-ṣanāì‘ (Beirut: Dār al-Kutub al-‘Ilmiyya, 2003), 10:445-6. 


\section{A case from $17^{\text {th }}$-century Catholic Spain at the intersection of early marriage, marriage annulment, genital defects, and infertility}

The multi-layered connections between infertility and accusations of female genital defects are dramatically illustrated in a court case from $17^{\text {th }}$-century Catholic Spain. In this case, the husband seeks to end his marriage on the grounds that his wife is incapable of sexual intercourse due to genital defects. As the case unfolds, it becomes clear that he is in fact concerned about his wife's infertility, and that her infertility was itself the final consequence of a series of events stemming from his marriage to a physically immature girl who, it seems, was not initially acknowledged to be so young. Many of the social concerns and actions described here echo the technical language and seemingly obscure medical situations found in Islamic legal texts and flesh them out. At the same time, we must keep in mind the obviously divergent legal and social attitudes toward divorce in the Christian and Islamic worlds.

The following summary of the case is derived from the original scholarship of Edward Behrend-Martínez. ${ }^{138}$ Magdalena Fernández de Valasco Sáenz's husband Pedro brought her to the court of Calahorra in 1697 to enter a plea for annulment on the charge of her impotence. Pedro's lawyer alleged that the previously-married father-of-three had found that his sixteen-year old bride's vagina was too narrow "for reception of the material that serves for the preservation of the species." ${ }^{\prime 39}$ He complained to her natal family and her mother then attempted "to open and/or expand [Magdalena's] vagina using hands and instruments." 140 This, however, did not remedy the problem so Pedro turned to the court to put an end to the marriage.

In court, Pedro's lawyer complained that Magdalena was incapable of conceiving. The judge ordered an expert medical examination which concluded that Magdalena was small and had not yet reached menarche. It also found that Magdalena's genitals had been forced open by an instrument, leaving her mutilated and sterile. Magdalena's lawyer accused Pedro of injuring her by having intercourse with her when she was of "such a tender age." ${ }^{141}$ The lawyer then said she only needed time to sexually mature and then she would be able to con-

138 See E. Behrend-Martínez, "Female Sexual Potency in a Spanish Church Court, 1673-1735," Law and History Review 24.2 (2006), 297-330. Also, E. Behrend-Martínez, Unfit for Marriage: Impotent Spouses On Trial In the Basque Region of Spain, 1650-1750 (Reno: University of Nevada Press, 2007), 71-73. I have not studied the primary sources in their original languages.

139 Behrend-Martínez, "Female Sexual Potency in a Spanish Church Court, 1673-1735," 318.

140 Behrend-Martinez, Unfit for Marriage, 72.

141 Behrend-Martínez, "Female Sexual Potency in a Spanish Church Court, 1673-1735," 318. 
summate the marriage and produce children. The lawyer said that this had also happened in his own family. ${ }^{142}$ A second medical examination was ordered which found that Magdalena was not sixteen years old, but "about twelve." The court declared Magdalena impotent and annulled the marriage.

As with Sunnì law, in Spanish law infertility was not considered to be grounds for annulment, however, the inability to consummate the marriage due to genital defects did constitute such grounds. Canon law acknowledged "female impotence" as grounds for annulment beginning in the twelfth century. ${ }^{143}$ Definitions of female impotence in the Catholic context closely resembled Islamic discussions of legal defects pertaining to women's genitals, particularly as both focus on purported vaginal blockages. ${ }^{144}$ For example, Gratian's Decretals described three types of female impotence: a narrow vagina, a blocked vagina, or a tumor which has closed the entrance to the uterus. ${ }^{145}$ Charges of female impotence were sometimes brought to court only after several years of marriage, indicating that the problem experienced by the couple was one which took years to surface, and thus was not likely to be a problem in actually consummating the marriage, ${ }^{146}$ and sometimes these lawsuits, ostensibly about the charge

142 The scenario in which at first a woman is labeled as impotent (impossible to penetrate), and then later on is able to have normal sexual relations, is dealt with in the law code Sieta Parditas. Las Siete Partidas, tr. Samuel Parsons Scott (Chicago: The Comparative Law Bureau of The American Bar Association, 1931) 4:914. This condition seems to be one which resolves itself with the passage of time.

143 Behrend-Martínez, "Female Sexual Potency in a Spanish Church Court, 1673-1735," 316. 144 P. Darmon, Trial by Impotence: Virility and Marriage in Pre-Revolutionary France (London: Hogarth Press, 1985), 16. In the $12^{\text {th }}-13^{\text {th }}$ centuries A.D. there appears to have been some intellectual tension between the desire of Catholic religious authorities to encourage those stuck in marriages with an impotent partner to live "as brother and sister," and their reasoning that annulment would prevent more licentious forms of behavior (i.e. alternative forms of sexual behavior between spouses, or adultery.) This briefly culminated a decision by Pope Celestine IV, whose papacy lasted for less than 3 weeks of 1241, to issue a decree which allowed a husband, whose wife's genitals were too narrow, "both to keep her in his house and to remarry." Darmon, Trial by Impotence, 65. There is no evidence that such permission to engage in bigamy was ever legally implemented. For more on the religio-legal problems associated with such conditions see, C. S. Pinheiro, "The Medical Sources in the Chapters about Sterility of Rodrigo de Castro's De universa mulierum medicina," in Gayle Davis and Tracey Loughran, The Palgrave Handbook of Infertility In History: Approaches, Contexts and Perspectives (London: Palgrave Macmillan, 2017), 302.

145 Corpus iuris canonici Lib. 4, Tit. 15, Cap. 1 "De frigidis et maleficiatis, et impotentia coeundi."

146 This is not to suggest that charges of female impotence never occurred towards the beginning of a marriage. In fact, they seem to have often been leveled in response to charges of male impotence. In part, this can be attributed to canon law, which would have permitted the non-impotent spouse in an annulled marriage to remarry, but would have forbidden the other spouse from doing 
of female impotence, were focused on the ability to become pregnant ${ }^{147}$ BehrendMartinez writes:

Regardless of canon law, however, which did not allow for annulments based on sterility, one of the rhetorical concerns that the prosecution expressed in this case was that Magdalena was useless for the propagation of the species. Again, court rhetoric conflated female potency with fertility. Her vagina "could [not] permit the introduction of the material that serves for reproduction.” After being mutilated by either her mother or husband, Magdalena's defect was probably no longer whether she could have sex or not but whether she could bear children. Therefore, the concern for the lack of sexual "potency" was specifically anxiety over reproductive capacity: she could not give Pedro any more children than he already had.

The ability of an individual to reproduce was an issue in impotence cases, even though sterility was not an allowable cause for annulment under the law. The fact that sterility could not be directly considered was clear to the court and prosecutors; there were no annulment cases in which sterility was the central plea and very few mentioned it at all, but this did not prevent sterility from becoming a fundamental trial issue. ${ }^{148}$

Such cases demonstrate the connection between legal discussions of theoretical vaginal blockages and the practical desire to dissolve marriages to barren women.

In Magdalena's case, the accused wife really does seem to be physically unable to consummate the marriage. The testimonies suggest that this might be because she is very young. In addition to being small, she is premenarchal, and it seems that she, her parents, or her husband or perhaps all of them are either ig-

so. However, this phenomenon also occurd among Jews. Thus in a case addressed to Bezalel $\mathrm{b}$. Avraham al-Ashkenazi, a $16^{\text {th }}$-century rabbi born in Jerusalem and educated in Egypt, we are informed that "Reuven was wed to Dina, but was unable to have normal intercourse with her. He went around saying that she was sealed closed and needed to be opened with a lancet, while her relatives went around saying that Reuven was impotent. When the two engaged in fights [the community?] sought to correct/rebuke the woman but did not succeed. And so Reuven initiated Jewish court proceedings and brought women with expertise in this matter as witnesses, but nonetheless the woman's relatives would not give in to the law. Instead, they went to the gentile law and removed from Reuven's possession the trousseau and all the gifts, and then they convinced him to divorce her - according to the testimony of widespread knowledge coming from those who know of the outrage done to Reuven.” Ashkenazi, She'elot u-teshuvot Rabenu Betsalel Ashkenazi (New York: Feldman, 1955), folio 31, question 15. Cf. T. Rosen and U. Kfir, "What Does a Father Want?: An Unpublished Poem and Its Intertexts," in Studies in Arabic and Hebrew Letters in Honor of Raymond P. Scheindlin, ed. J. Decter and M. Rand (Piscataway, NJ: Gorgias Press, 2007), 129-53. Pp. 136-137 include the case of a twelve-year-old Jewish bride who is brutalized by both her impotent young husband and her parents for her perceived sexual faults.

147 Behrend-Martínez, "Female Sexual Potency in a Spanish Church Court, 1673-1735," 317. 148 Ibid., 319-320. 
norant, or pretending to be ignorant, of her true age. In attempting to consummate the marriage, either her husband or her mother, and possibly her medical examiner, injure and mangle her internal sex organs, thus rendering her infertile as well. In this case, therefore, female infertility is both the central fear motivating concerns about female sexual impotence, and it is also the product of attempts to cure that impotence. "Impotence" is in turn a result of, or at least highly correlated to, marriage consummation at an early age, a topic we shall return to in the next chapter.

How much of this is relevant to an Islamic legal context? Several key aspects of the situation have parallels in the pre-modern Islamic world. As we shall see, Magdalena's age and pre-menarchal status at the time of marriage are similar to ages commonly found in the Islamic world. The disputes surrounding the need for patience for the young wife's physical immaturity are found in the Islamic context as well. The physical defect of which she is accused also has parallels found throughout Islamic legal theoretical literature about genital defects. So too do the interventions embarked upon by the mother, interventions which cause further damage to the girl's sexual organs. The description of the damage to Magdalena's sexual organs and fertility by these efforts also seems to match the condition of ratq as described in medieval Islamic texts. What is not clear, however, is whether we should read medieval Islamic allegations of female genital defects in light of this Catholic legal stratagem: i.e. those allegations of genital defects existed to provide legal cover for dealing with what was primarily a fertility complaint. The argument in opposition to such a reading is that a Muslim husband did not need such a strategy, since he had the option of divorcing his wife. The argument in favor of such a reading is that some Muslim husbands and some Muslim wives, or their families, clearly did want to end their marriages via annulment rather than by divorce. They attempted to do so by arguing retroactively that the wife was not in a position to marry, either because she had a genital defect, or because she had been married off when she was a minor in an improper fashion, or because she had not yet completed her 'idda (waiting period) from a previous marriage. ${ }^{149}$ We thus see that, while the jurists almost never granted official recognition of the notion that infertility itself constitutes a basis for ending a marriage, they did recognize as legitimate grounds for annulment physical defects that were highly correlated with infertility.

149 E. g. al-Wansharīsī, al-Mi'yār al-Mu'rib, 3:48-9, 245, 266. 